\title{
KAJIAN PENENTUAN AWAL MUSIM DI DAERAH NON ZOM 14 RIAU DENGAN MENGGUNAKAN DATA CURAH HUJAN DAN HARI HUJAN
}

\author{
Aristya Ardhitama ${ }^{1 *}$, Rias Sholihah ${ }^{2 *}$
}

\begin{abstract}
Intisari
Daerah Riau termasuk kedalam wilayah ZOM (Zona Musim) dan Non ZOM. Daerah Non ZOM merupakan daerah-daerah yang tidak mempunyai batas yang jelas secara klimatologis antara periode musim hujan dan musim kemarau. Propinsi Riau memiliki wilayah Non ZOM 14 yang menurut teori tidak memilki perbedaan musim hujan dan musim kemarau. Dalam kajian penelitian ini penulis ingin membuktikan bahwa daerah Non ZOM 14 terdapat musim hujan dan musim kemarau. Data yang digunakan adalah data curah hujan $(\mathrm{CH})$ dan hari hujan $(\mathrm{HH})$ dasarian yang diambil dari stasiun daerah Dumai dan Sungai Pakning untuk menentukan Awal Musim. Dari hasil penelitian yang didapatkan daerah Non Zom 14 memiliki pola musim hujan dan musim kemarau yaitu awal musim kemarau yang pertama jatuh pada dasarian bulan Feb I sampai Feb III dan terjadi kembali pada bulan Mei II sampai bulan Juli II diperoleh hari hujan sebesar $\leq$ 2(HH) dengan nilai $\mathrm{CH}$ sebesar $<30 \mathrm{~mm}$. Awal musim hujan yang pertama terjadi pada dasarian pada bulan Maret I sampai bulai Mei II, kemudian musim hujan kembali terjadi pada bulan Juli II sampai bulan Desember II yang diperoleh dari hari hujan $\geq 4(\mathrm{HH})$ dengan batas $\mathrm{CH}$ sebesar $>50 \mathrm{~mm}$ diperoleh besar jumlah $\mathrm{CH} \geq 100 \mathrm{~mm}$. Sehingga dapat disimpulkan untuk daerah Non ZOM 14 Riau dapat direkomendasikan menjadi daerah ZOM (Zona Musim).
\end{abstract}

\begin{abstract}
Riau area included into the territory of ZOM (Season Zone) and Non ZOM. The Non ZOMS were areas that do not have a clear limit for climatologist between the period of rainy season and dry season. Riau Province has an area of 14 which according to Non ZOMS theory do not have differences in rainy season and dry season. In this research studies the author want to prove that the Non ZOMS 14 there is a rainy season and a dry season. The data used are the precipitation data $(\mathrm{CH})$ and rainy day $(\mathrm{HH})$ decade taken from local station in Dumai and Sungai Pakning to determine the start of the season. From the results obtained by research area Non Zoms 14 has the pattern of rainy season and dry season is the beginning of the dry season the first fell on the decade month of Feb I until Feb III and going back in May II until July II obtained a rainy day at $\leq 2$ (HH) with $\mathrm{CH}$ value $<30 \mathrm{~mm}$. the Beginning of the rainy season the first one occurred at decade in March I until May II, later rainy season occurred in july II until december II obtained from rainy days $\geq 4(\mathrm{HH})$ with limits of $\mathrm{CH}>$ gained an enormous amount of $\mathrm{CH}$ $50 \mathrm{~mm} \geq 100 \mathrm{~mm}$. so it can be inferred for the Non ZOMS 14 Riau can be recommended to be ZOMS (zone seasons).
\end{abstract}

Kata Kunci: Awal musim, Non ZOM, Curah hujan, Hari hujan

\section{PENDAHULUAN}

Propinsi Riau terletak antara $4^{\circ} 45^{\prime}$ lintang utara dan $1^{\circ} 15^{\prime}$ lintang selatan, $100^{\circ} 43^{\prime}$ - $109^{\circ} 19^{\prime}$ bujur timur, Provinsi Riau merupakan wilayah yang berbatasan dengan Kepulauan Riau di sebelah utara dan Selat Melaka, di sebelah selatan dengan Provinsi Jambi dan Selat Berhala, di sebelah timur berbatasan dengan Laut Cina Selatan (Provinsi Kepulauan Riau) dan di sebelah barat berbatasan dengan Provinsi Sumatera Barat dan Provinsi Sumatera Utara. Riau memiliki tipe yaitu curah hujan ekuatorial. Dipengaruhi oleh bukit barisan dan pengaruh dari angin darat dan laut dar selat malaka.

Provinsi Riau beriklim tropis basah dengan rata rata curah hujan berkisar antara 1000-3000 $\mathrm{mm}$ per tahun yang dipengaruhi oleh musim kemarau dan musim hujan. Daerah yang paling sering ditimpa hujan setiap tahun adalah Kota Pekanbaru 193 hari, Kabupaten Indragiri Hulu 178 hari, Kabupaten Pelalawan 147 hari, Kabupaten Rokan Hulu 136 hari, dan Kabupaten Kampar denganjumlah hari hujan 110 hari. Jumlah Curah Hujan tertinggi pada tahun 2009 terjadi di Kabupaten Kampar dengan curah hujan sebesar $3.349 \mathrm{~mm}$, disusul Kota Pekanbaru sebesar

1) PMG Muda Stasiun Meteorologi Pekanbaru, 2) Geofisika dan Meteorologi-FMIPA-IPB ardhi.tama@gmail.com, riassholihah.sb94@gmail.com 
3.214,4 mm, sedangkan curah hujan terendah terjadi di Kota Dumai sebesar $635,0 \mathrm{~mm}$. Selanjutnya menurut catatan Stasiun Meteorologi Simpang Tiga, suhu udara rata rata di Kota Pekanbaru tahun 2009 menunjukkan $28^{\circ}$ celcius dengan suhu maksimum 36,0 celcius dan suhu minimum $21^{\circ}$ celcius.

Pola curah hujan di Indonesia juga dipengaruhi oleh keberadaan deretan pegunungan. Pegunungan merupakan penghalang fisik bagi pergerakan angin. Hujan orografis akan terjadi jika udara lembab terdorong naik karena per gerakannya terhalang oleh keberadaan pegunungan, Curah hujan untuk sisi arah datang angin lembab (wind-ward side) akan tinggi dan pada sisi pegunungan disebelahnya curah hujan akan sangat rendah ${ }^{[19]}$

Salah satu penyebab perubahan curah hujan di Indonesia, termasuk juga di sebagian besar belahan dunia adalah ENSO (EI NinoSouthern Oscillation) atau sering disebut El Nino. Fenomena El Nino ditandai oleh terjadinya pergeseran kolam hangat yang biasanya berada di perairan Indonesia ke arah timur (Pasifik Tengah) yang diiringi oleh pergeseran lokasi pembentukan awan yang biasanya terjadi di wilayah Indonesia ke arah timur yaitu di Samudra Pasifik Tengah ${ }^{[13]}$.

Ada beberapa pengertian yang berkaitan dengan cuaca; menurut Trewartha $(1980)^{[19]}$, cuaca adalah keadaan variabel atmosfer secara keseluruhan disuatu tempat dalam selang waktu yang pendek. Sedangkan menurut Gibbs $(1987)^{[7]}$, cuaca adalah keadaan atmosfer yang dinyatakan dengan nilai berbagai parameter, antara lain suhu, tekanan, angin, kelembaban, dan berbagai fenomena hujan, disuatu tempat atau wilayah selama kurun waktu yang pendek.

Selain faktor cuaca ada hal lain yang berkaitan dengan cuaca yang disebut dengan iklim. Iklim memiliki pengertian yaitu konsep abstrak yang menyatakan kebiasaan cuaca dan unsur-unsur atmosfer disuatu daerah selama kurun waktu yang panjang ${ }^{[18]}$. Sedang menurut Gibbs $(1987)^{[20]}$, iklim adalah peluang ststistik berbagai keadaan atmosfer, antara Propinsi Riau merupakan wilayah daratan dan kepulauan yang berada pada ketinggian antara 0-200 meter di atas permukaan laut. Wilayah ini memiliki perairan umum yang berupa sungai. Iklim daerah Riau termasuk tropis basah yang dipengaruhi oleh musim hujan dan musim kemarau, dengan curah hujan cukup merata antara 2.500-3.000 milimeter setiap tahun. Suhu udara beragam antara $21^{\circ} \mathrm{C}$ elsius $-31^{\circ} \mathrm{C}$ elsius. Selain itu, Propinsi Riau merupakan jalur ekuator sehingga membentuk pola curah hujan ekuatorial yang menyebabkan daerah Dumai dan Sei. Pakning memiliki curah hujan yang besar (Musim Hujan).

Pola hujan ekuatorial memiliki dua puncak hujan yang terjadi saat matahari berada dekat ekuator, yaitu sekitar bulan Maret dan Oktober ${ }^{[17]}$. Pola ekuatorial dibagi menjadi tipe $D$ dan tipe $E$. Tipe D mencakup wilayah pantai barat Sumatera Utara, sedangkan tipe E mencakup daerah wilayah pantai barat Sumatera Selatan. Pada wilayah ini musim kemarau tidak begitu jelas ${ }^{[4]}$.

Daerah Riau termasuk kedalam wilayah ZOM (Zona Musim) dan Non ZOM. Daerah Non ZOM merupakan daerah-daerah yang tidak mempunyai batas yang jelas secara klimatologis antara periode musim hujan dan musim kemarau. Propinsi Riau memiliki wilayah Non ZOM 14 yang menurut teori tidak memilki perbedaan musim hujan dan musim kemarau. Dalam kajian penelitian ini penulis ingin membuktikan bahwa daerah Non ZOM 14 terdapat musim hujan dan musim kemarau.

\section{TINJAUAN TEORI 2.1 Hujan}

Hujan merupakan salah satu bentuk presipitasi uap air yang berasal dari awan yang terdapat di atmosfer. Bentuk presipitasi lainnya adalah salju dan es. Untuk dapat terjadinya hujan diperlukan titik-titik kondensasi, amoniak, debu dan asam belerang. Titik-titik kondensasi ini mempunyai sifat dapat mengambil uap air dari udara. Satuan curah hujan selalu dinyatakan dalam satuan millimeter atau inchi namun untuk di Indonesia satuan curah hujan yang digunakan adalah dalam satuan millimeter $(\mathrm{mm})$. Hujan merupakan salah satu fenomena alam yang terdapat dalam siklus hidrologi dan sangat dipengaruhi iklim. Keberadaan hujan sangat penting dalam kehidupan, karena hujan dapat mencukupi kebutuhan air yang sangat dibutuhkan oleh semua makhluk hidup. Hydrometeor yang jatuh ke tanah disebut hujan sedangkan yang tidak sampai tanah disebut Virga ${ }^{[7]}$.

Hujan yang sampai ke permukaan tanah dapat diukur dengan jalan mengukur tinggi air hujan tersebut dengan berdasarkan volume air hujan per satuan luas. Hasil dari pengukuran tersebut dinamakan dengan curah hujan. Curah hujan merupakan salah satu unsur cuaca yang datanya diperoleh dengan cara mengukurnya dengan menggunakan alat penakar hujan, sehingga dapat diketahui jumlahnya dalam satuan millimeter $(\mathrm{mm})$. Curah hujan $1 \mathrm{~mm}$ adalah jumlah air hujan yang jatuh di permukaan per satuan luas $\left(\mathrm{m}^{2}\right)$ dengan catatan tidak ada yang menguap, meresap atau mengalir. Jadi, curah hujan sebesar 
$1 \mathrm{~mm}$ setara dengan $1 \mathrm{liter} / \mathrm{m}^{2[1]}$. Curah hujan dibatasi sebagai tinggi air hujan yang diterima di permukaan sebelum mengalami aliran permukaan, evaporasi dan peresapan ke dalam tanah.

Hujan merupakan unsur fisik lingkungan yang paling beragam baik menurut waktu maupun tempat dan hujan juga merupakan faktor penentu serta faktor pembatas bagi kegiatan pertanian secara umum. Oleh karena itu klasifikasi iklim untuk wilayah Indonesia (Asia Tenggara umumnya) seluruhnya dikembangkan dengan menggunakan curah hujan sebagai kriteria utama ${ }^{8] .}$ Bayong (2004) $)^{[4]}$ mengungkapkan bahwa dengan adanya hubungan sistematik antara unsur iklim dengan pola tanam dunia telah melahirkan pemahaman baru tentang klasifikasi iklim, dimana dengan adanya korelasi antara tanaman dan unsur suhu atau presipitasi menyebabkan indeks suhu atau presipitasi dipakai sebagai kriteria dalam pengklasifikasian iklim.

Sifat hujan terbagi atas tiga kategori ${ }^{[17]}$ :

1) Hujan Normal adalah jika nilai curah hujan antara $85 \%-115 \%$ dari normalnya.

2) Hujan Dibawah Normal adalah jika nilai curah hujan dibawah $85 \%$ dari normalnya.

3) Hujan Diatas Normal adalah jika nilai curah hujan diatas $115 \%$ dari nilai normalnya.

Sedangkan jenis hujan ada tiga yaitu ${ }^{[17]}$ :

1) Hujan konvektif, adalah akibat dari pemanasan dari radiasi matahari, udara permukaan akan mamuai dan naik ke atas, kemudian udara yang naik akan mengembun. Gerakan vertikal udara lembab yang mengalami pendinginan dengan cepat akan menghasilkan hujan deras.

2) Hujan orografik adalah jika pergerakan udara melalui pegunungan atau bukit yang tinggi, maka udara akan di paksa naik. Setelah terjadi kondensasi, tumbuh awan pada lereng di atas angin (windward side) dan hujannya disebut hujan orografik, sedangkan pada lereng di bawah angin (leeward side) udara yang turun akan mengalami pemanasan dengan sifat kering, dan daerah ini disebut daerah bayangan hujan.

3) Hujan konvergensi dan frontal adalah jika ada konvergensi pada arus udara horizontal dari masa udara yang besar dan tebal, maka akan terjadi gerakan ke atas. Kenaikan udara di daerah konvergensi dapat menyebabkan pertumbuhan awan dan hujan. Jika massa dua udara yang konvergen horizontal mempunyai suhu dan masa jenis berbeda, maka massa udara yang lebih panas akan dipaksa naik di atas massa udara yang dingin. Bidang batas antara kedua massa udara yang berbeda sifat fisisnya disebut front.
BMKG $^{[5]}$ Berdasarkan distribusi data ratarata curah hujan bulanan, umumnya wilayah Indonesia dibagi menjadi 3 (tiga) pola hujan, yaitu : 1. Pola hujan monsun, yang wilayahnya memiliki perbedaan yang jelas antara periode musim hujan dan periode musim kemarau kemudian dikelompokan dalam Zona Musim (ZOM), tipe curah hujan yang bersifat unimodial (satu puncak musim hujan, DJF musim hujan, JJA musim kemarau).

2. Pola hujan equatorial, yang wilayahnya memiliki distribusi hujan bulanan bimodial dengan dua puncak musim hujan maksimum dan hampir sepanjang tahun masuk dalam kreteria musim hujan. Pola ekuatorial dicirikan oleh tipe curah hujan dengan bentuk bimodial (dua puncak hujan) yang biasanya terjadi sekitar bulan Maret dan Oktober atau pada saat terjadi ekinoks.

3. Pola hujan lokal, yang wilayahnya memiliki distribusi hujan bulanan kebalikan dengan pola monsun. Pola lokal dicirikan oleh bentuk pola hujan unimodial (satu puncak hujan), tetapi bentuknya berlawanan dengan tipe hujan monsun.

Pada kondisi normal, daerah yang bertipe hujan monsun akan mendapatkan jumlah curah hujan yang berlebih pada saat monsun barat (DJF) dibanding saat monsun timur (JJA). P Pengaruh monsun di daerah yang memiliki pola curah hujan ekuator kurang tegas akibat pengaruh insolasi pada saat terjadi ekinoks, demikian juga pada daerah yang memiliki pola curah hujan lokal yang lebih dipengaruhi oleh efek orografi ${ }^{\left[{ }^{[]} \text {. }\right.}$

Presipitasi adalah peristiwa turunnya air ke permukaan bumi, yang bisa berupa hujan, hujan salju, kabut, embun dan hujan es. Di daerah tropis, termasuk Indonesia, yang memberikan sumbangan paling besar adalah hujan sehingga seringkali hujanlah yang dianggap sebagai presipitasi. Hujan berasal dari uap air di atmosfer, sehingga bentuk dan jumlahnya dipengaruhi oleh faktor klimatologi seperti angin, temperatur, dan tekanan atmosfer. Uap air tersebut akan naik ke atmosfer sehingga mendingin dan terjadi kondensasi menjadi butir butir air dan kristal kristal es yang akhirnya jatuh sebagai hujan.

Terjadinya hujan karena adanya perpindahan massa uap air ke tempat yang lebih tinggi sebagai respon adanya beda tekanan udara antara dua tempat yang berbeda ketinggiannya. Di tempat tersebut, karena akumulasi uap air pada suhu yang rendah maka terjadilah proses kondensasi, dan pada gilirannya massa uap air tersebut jatuh sebagai air hujan. Namun demikian, mekanisme berlangsungnya hujan melibatkan tiga faktor utama. Dengan kata lain, akan terjadi hujan apabila berlangsung tiga kejadian sebagai berikut 1) 
1. Kenaikan massa uap air ke tempat yang lebih tinggi sampai saatnya atmosfer menjadi jenuh.

2. Terjadi kondensasi atas partikel-partikel uap air di atmosfer.

3. Partikel - partikel uap air tersebut bertambah besar sejalan dengan waktu untuk kemudian jatuh ke bumi dan permukaan laut (sebagai hujan) karena gravitasi.

Hujan sangat dipengaruhi oleh iklim dan keadaan topografi daerah,sehingga keadaanya sangat berbeda untuk masing -masing daerah ${ }^{2)}$.

Satu indikasi yang dapat dilihat adalah kecenderungan curah hujan. Manton et al (2001) menjelaskan bahwa kecenderungan curah hujan dan suhu setiap hari ekstrim di beberapa Negara di Asia Tenggara dan Australia, termasuk Indonesia. Terutama untuk wilayah Indonesia, mereka memakai enam pusat curah hujan, yang mana mereka dapat menyimpulkan bahwa jumlah hari-hari hujan (dengan paling sedikit 2 $\mathrm{mm}$ curah hujan) telah menurun drastis di Asia Tenggara dan di Bagian Barat serta Pusat Pasifik Selatan, tetapi meningkat di bagian utara French Polynesia, Fiji dan beberapa titik di Australia. Akan tetapi, penelitian ini kelihatan kurang cukup untuk menjelaskan di wilayah khusus dan kompleks seperti di Indonesia.

\subsection{Kemarau}

Musim kemarau atau musim kering adalah musim di daerah tropis yang dipengaruhi oleh sistem muson. Untuk dapat disebut musim kemarau, curah hujan per bulan harus di bawah 60 $\mathrm{mm}$ per bulan (atau $20 \mathrm{~mm}$ per dasarian) selama tiga dasarian berturut-turut. Wilayah tropika di Asia Tenggara dan Asia Selatan, Australia bagian timur laut, Afrika, dan sebagian Amerika Selatan mengalami musim ini. Musim kemarau adalah pasangan dari musim penghujan dalam wilayah dwimusim. Musim Kemarau panjang adalah Musim Kemarau yang sangat panas dengan jangka waktu yang panjang ${ }^{[6]}$

\subsection{ZOM dan Non ZOM}

Berdasarkan pengelompokan pola distribusi curah hujan rata-rata bulanan di seluruh wilayah Indonesia, maka secara klimatologis wilayah Indonesia terdiri atas :

a. Daerah-daerah yang mempunyai batas yang jelas secara klimatologis antara periode musim hujan dan periode musim kemarau, yang selanjutnya disebut daerah Zona Musim ( ZOM ) .

b. Daerah-daerah yang tidak mempunyai batas yang jelas secara klimatologis antara periode musim hujan dan musim kemarau, yang selanjutnya disebut daerah Non Zona Musim (Non ZOM ).

Berdasarkan hasil pengolahan dan analisis data periode 30 tahun (tahun 1981 -2010), wilayah Indonesia terdiri atas 342 Zona Musim (ZOM), yaitu Sumatera 54 ZOM, Jawa 150 ZOM, Bali 15 ZOM, Nusa Tenggara Barat 21 ZOM, Nusa Tenggara Timur 23 ZOM, Kalimantan 22 ZOM, Sulawesi 42 ZOM, Kepulauan Maluku 9 ZOM dan Papua 6 ZOM. Dari 342 Zona Musim, sebanyak 9 ZOM memiliki pola hujan berkebalikan dengan daerah zona musim pada umumnya (pola monsun), dimana saat daerah pola monsun mengalami musim hujan, di daerah 9 ZOM tersebut mengalami musim kemarau, dan demikian sebaliknya. Kesembilan ZOM tersebut meliputi 7 ZOM di Sulawesi Selatan dan 2 ZOM di Maluku.

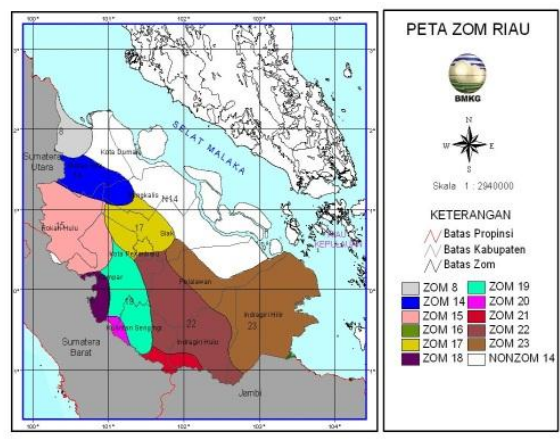

Gambar 1 Peta ZOM (Zona Musim) Daerah $\mathrm{Riau}^{[4]}$

\subsection{Awal dan panjang musim wilayah}

Berdasarkan ketentuan yang dibuat oleh BMG, awal musim hujan ditandai dengan jumlah curah hujan dasarian telah lebih dari $50 \mathrm{~mm}$ dan diikuti minimal dua dasarian berikutnya, sebaliknya awal musim kemarau ditandai dengan jumlah curah hujan dasarian kurang dari $50 \mathrm{~mm}$ dan diikuti minimal dua dasarian berikutnya. Panjang musim hujan adalah jumlah dasarian antara awal musim hujan sampai dengan awal musim kemarau berikutnya, sedangkan panjang

Musim kemarau adalah jumlah dasarian antara awal musim kemarau sampai dengan awal musim hujan berikutnya. Normal 20 tahun awal dan panjang musim dihitung berdasarkan pola normal 20 tahun curah hujan dasarian di tiap wilayah atau kelompok.

\subsection{Definisi Awal Musim}

Awal musim didefinisikan sebagai dasarian awal mulainya musim. (BMKG) mengeluarkan aturan bahwa untuk permulaan musim kemarau, jumlah curah hujan dalam satu dasarian (10 hari) kurang dari 50 milimeter dan diikuti oleh beberapa 
dasarian berikutnya. Permulaan musim kemarau, bisa terjadi lebih awal (maju), sama, atau lebih lambat (mundur) dari normalnya (rata-rata 19812010). Sedangkan untuk permulaan musim hujan, jumlah curah hujan dalam satu dasarian (10 hari) sama atau lebih dari 50 milimeter dan diikuti oleh beberapa dasarian berikutnya. Permulaan musim hujan, bisa terjadi lebih awal (maju), sama, atau lebih lambat (mundur) dari normalnya (rata-rata $1981-2010)^{[12]}$.

Awal musim hujan atau kemarau di setiap daerah untuk setiap tahunnya berbeda-beda tergantung pada faktor kondisi dan tatanan cuaca lainnya dalam skala besar. Panjang musim pun di setiap daerah berbeda-beda sesuai dengan letak geaografisnya, unsur cuaca/iklim Indonesia mempunyai variasi musiman. Variasi musiman tersebut dapat jelas terlihat pada curah hujan. Oleh karena itu di Indonesia dikenal dengan musim hujan dan musim kemarau. Kedua musim tersebut dibedakan dari banyaknya curah hujan. Pada umumnya sewaktu matahari berada di belahan bumi selatan dari bulan Oktober sampai Maret, curah hujan akan lebih banyak jika dibandingkan sewaktu matahari berada di belahan bumi utara dari bulan April sampai september. Namun, di daerah-daerah tertentu belum tentu demikian karena adanya faktor local ${ }^{[5]}$

Definisi secara umum, yaitu:

1. Awal Musim hujan

Bilamana jumlah curah hujan selama satu dasarian (10 hari) sama atau lebih dari 50 milimeter serta diikuti oleh dasarian berikutnya.

2. Awal Musim kemarau

Bilamana jumlah curah hujan selama satu dasarian (10 hari) kurang dari 50 milimeter serta diikuti oleh dasarian berikutnya ${ }^{[5]}$

\section{$2.7 \quad$ Tipe Ekuatorial}

Pola ini berhubungan dengan pergerakan zona konvergensi ke arah utara dan selatan mengikuti per gerakan semu matahari. Zone konver gensi merupakan pertemuan dua massa udara (angin) yang berasal dari dua belahan bumi, kemudian udaranya ber gerak ke atas. Angin yang ber gerak menuju satu titik dan kemudian ber gerakke atas disebut konvergensi, dan tempat terjadinya konvergensi disebut daerah konver gensi. Posisinya relatif sempit dan berada pada lintang rendah dan dikenal dengan nama Inter tropical Conver gence Zone (ITCZ) atau Daerah Konvergensi Antar Tropik (DKAT). ITCZ juga dikenal dengan nama ekuator panas (heat equator) atau front ekuator (equatorial front $t^{[155}$

Di atas lautan Atlantik dan Pasifik posisi ITCZ sangat dekat terhubung dengan "doldrums" (daerah $5^{\circ}$ LU-5노), maka ITCZ merupakan batas antara angin pasat utara-timuran dengan angin pasat selatan-timuran, sedangkan di atas benua pergeseran posisi ITCZ tampak lebih tegas. Sirkulasi monsun terhubung dengan pergeseran utara-selatan dari ITCZ, dan juga tergantung pada kontras musimandalam pemanasan daratan dan lautan sebagai suatu sistem yang kompleks ${ }^{[16]}$.

ITCZ bergerak ke arah utara pada musim panas di belahan bumi utara (bulan Juli) dan bergerak kearah selatan pada musim panas di belahan bumi selatan (bulan Januari) mengikuti lokasi pemanasan matahari maksimum, sehingga pada bulan Juli, yaitu saat terjadinya maksimum musim panas di belahan bumi utara, posisi ITCZ berada di sekitar $25^{\circ} \mathrm{LU}$ diatas benua Asia dan antara $5 \mathrm{~s} / \mathrm{d} 10^{\circ} \mathrm{LU}$ di atas lautan.

\section{METODOLOGI}

Data yang digunakan dalam penelitian ini adalah data sekunder yang diperoleh dari BMKG, dengan menggunakan data sebagai berikut:

> Data yang digunkan adalah data curah hujan dasarian $(\mathrm{CH})$ dan hari hujan dasarian $(\mathrm{HH})$ dengan mengunakan 2 wilayah kajian yang diambil dari stasiun daerah Dumai dan Sei. Pakning untuk menentukan daerah Non ZOM (Zona Musim)

> Untuk wilayah Dumai menggunakan data $\mathrm{CH}$ dan $\mathrm{HH}$ dari tahun 1980 sampai tahun 2014 selama 30 tahun (data normal)

> Untuk Sei. Pakning menggunakan data $\mathrm{CH}$ dan HH dari tahun 1990 sampi tahun 2014

> Data hujan harian Zona Musim Riau meliputi ZOM14,

> Dari data curah hujan harian yang dijadikan sampel, selanjutnya dihitung nilai curah hujan dasarian dan hari hujan dasarian dengan metode penjumlahan sederhana ${ }^{\text {[21]: }}$

$$
\mathrm{CH}_{\text {dasarian }}=\mathrm{CH}_{1}+\mathrm{CH}_{2}+\ldots+\mathrm{CH}_{\mathrm{n}}
$$

Suatu hari dikatakan sebagai hari hujan jika terdapat curah hujan diatas $0,0 \mathrm{~mm}$.

$H H_{\text {dasarian }}=\mathrm{HH}_{1}+\mathrm{HH}_{2}+\ldots .+\mathrm{HH}_{\mathrm{n}}$

Dimana $n$ adalah hari ke-10 dalam dasarian ke-I dan ke-II pada setiap bulan atau hari terakhir pada dasarian ke-III

- Penentuan awal musim hujan (AMH) dan awal musim kemarau (AMK) berdasarkan kriteria utama (curah hujan per dasarian) dengan mengambil satu sampel pos hujan. Selanjutnya, dikombinasikan karakteristik curah hujan dan hari hujan dari pos hujan sampel dengan berbagai kondisi yaitu ${ }^{[21]}$ :

Kondisi 1 :

$\mathrm{CH}$ per dasarian $\geq 50 \mathrm{~mm}$ dan $\mathrm{HH}$ per dasarian $\geq 3$ hari untuk $\mathrm{AMH}$

$\mathrm{CH}$ per dasarian $\geq 50 \mathrm{~mm}$ dan $\mathrm{HH}$ per dasarian $\geq 3$ hari untuk $\mathrm{AMH}$

Kondisi 2 : 
$\mathrm{CH}$ per dasarian $<50 \mathrm{~mm}$ dan $\mathrm{HH}$ per dasarian $\leq 3$ hari untuk AMK

$\mathrm{CH}$ per dasarian $<50 \mathrm{~mm}$ dan $\mathrm{HH}$ per dasarian $\leq 3$ hari untuk AMK

Kondisi 3 :

$\mathrm{CH}$ per dasarian $\geq 50 \mathrm{~mm}$ dan $\mathrm{HH}$ per dasarian $\geq 3$ hari untuk $\mathrm{AMH}$

$\mathrm{CH}$ per dasarian $\geq 50 \mathrm{~mm}$ dan $\mathrm{HH}$ per dasarian $\geq 3$ hari untuk $\mathrm{AMH}$

Kondisi 4 :

$\mathrm{CH}$ per dasarian $\geq 50 \mathrm{~mm}$ dan $\mathrm{HH}$ per dasarian $\geq 3$ hari untuk $\mathrm{AMH}$

$\mathrm{CH}$ per dasarian $\geq 50 \mathrm{~mm}$ dan $\mathrm{HH}$ per dasarian $\geq 3$ hari untuk $\mathrm{AMH}$

$\mathrm{CH}$ per dasarian $>50 \mathrm{~mm}$ dan $\mathrm{HH}$ per dasarian $\geq 3$ hari untuk $\mathrm{AMH}$

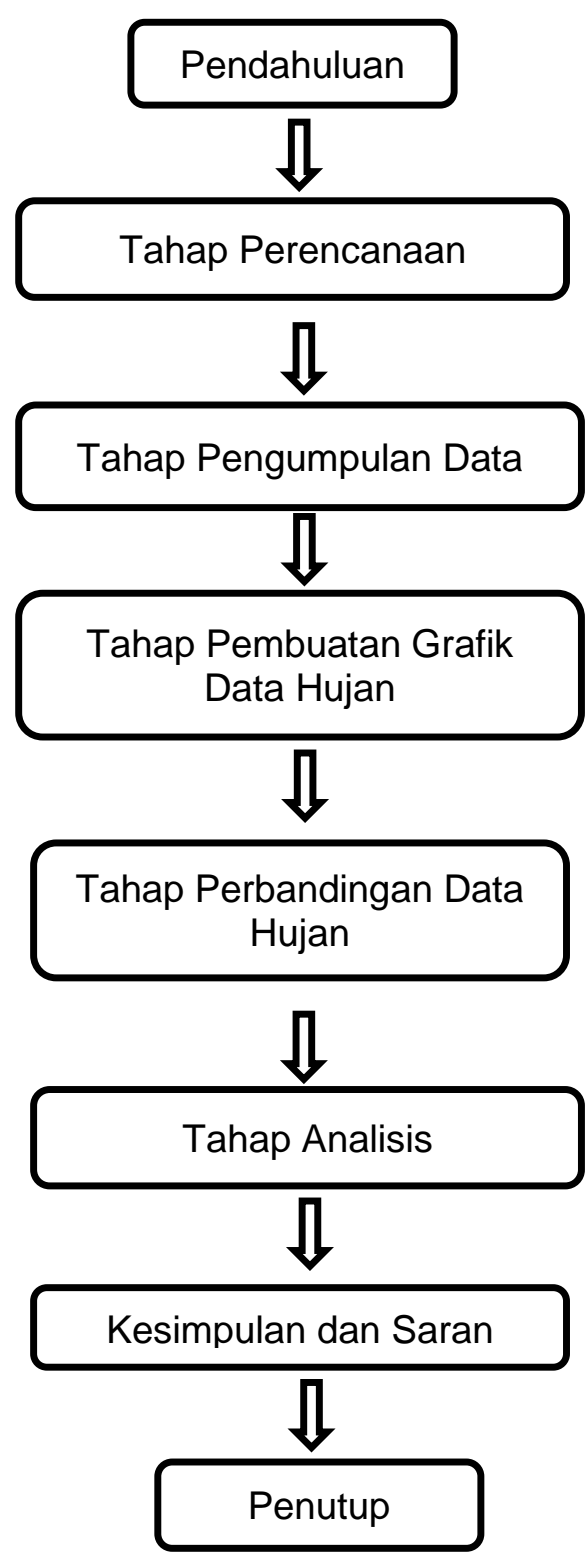

Gambar 2 Metode penelitian

\section{HASIL DAN PEMBAHASAN}

Dari hasil penelitian yang telah dilakukan dengan mengunakan metode jumlah $(\mathrm{CH})$ curah hujan dasarian, $(\mathrm{HH})$ hujan harian dasarian dan daerah Non ZOM (Zona Musim) serta mengetahui normal, awal musim (AMH dan AMK) di daerah Riau pada wilayah kajian daerah Dumai dan Sei. Pakning didapatkan hasil berikut:

\subsection{Dumai}

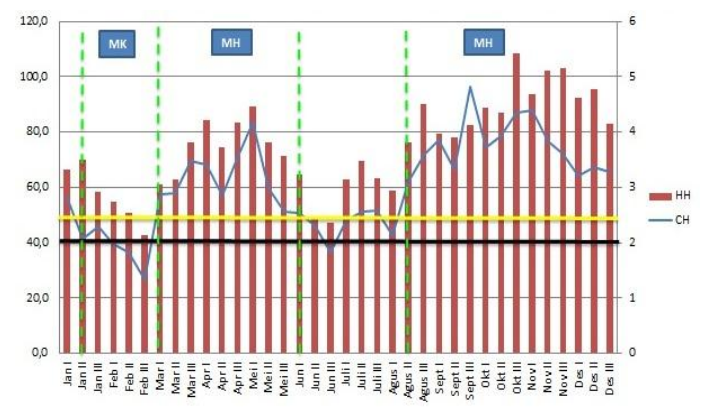

Gambar 3 Musim hujan di Dumai Periode Ke-I

Berdasarkan dari gambar diatas menunjukkan musim hujan di daerah Dumai untuk periode 1 terjadi pada bulan Maret I sampai Juni I kemudian dikuti kembali musim hujan yang jatuh pada bulan Agustus II sampai bulan Desember III. Musim hujan yang terjadi pada hari hujan $>2(\mathrm{HH})$ Pada 2 hari hujan di Dumai terlihat pada grafik yang menunjukkan $\mathrm{CH} \geq 50 \mathrm{~mm}(\mathrm{AMH})$.

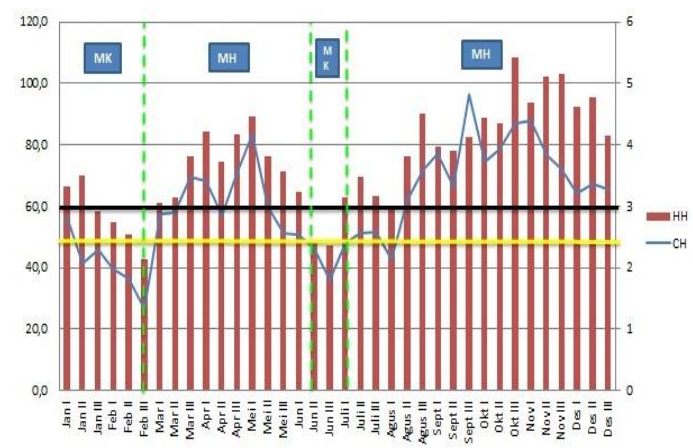

Gambar 4 Musim hujan di Dumai Periode Ke-II

Gambar diatas menunjukkan kondisi musim hujan di daerah Dumai periode ke 2 terjadi pada Feb II sampai Juni II kemudian terjadi kembali musim hujan pada bulan Agustus II sampai bulan Desember III yang terjadi pada hari hujan $\geq 3(\mathrm{HH})$. Pada gambar tersebut terlihat bahwa musim hujan dengan nilai $\mathrm{CH}$ sebesar $\geq 50$ $\mathrm{mm}$.

Pada kedua periode musim hujan yang terjadi di Dumai, seperti gambar diatas 
menjelaskan bahwa untuk wilayah Dumai musim hujan akan terjadi jika $\geq 3 \mathrm{HH}$ dengan besar curah hujan $\geq 50 \mathrm{~mm}$.

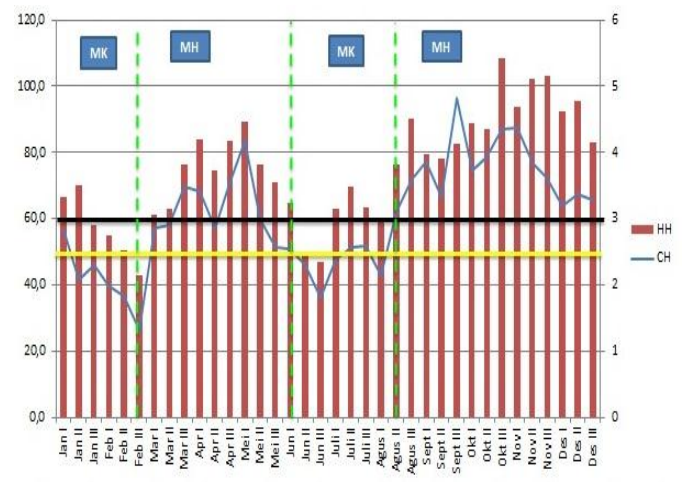

Gambar 5 Musim kemarau di Dumai Periode Ke-I

Berdasarkan gambar diatas menunjukkan musim kemarau di daerah Dumai pada hari hujan $\leq$ $3(\mathrm{HH})$ untuk priode 1 terjadi pada bulan Jan II sampai Feb III kemudian terjadi kembali musim kemarau pada bulan Juni I sampai bulan Agustus II. Pada gambar tersebut terlihat bahwa musim kemarau dengan nilai $\mathrm{CH}$ sebesar $\leq 50 \mathrm{~mm}$

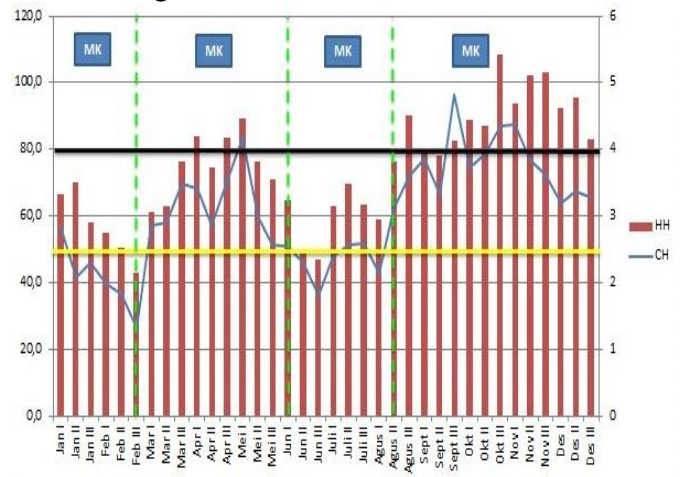

Gambar 6 Musim kemarau di Dumai Periode Ke-II

Gambar diatas menunjukkan kondisi daerah Dumai untuk periode 2 mengalami musim kemarau sepanjang waktu dalam setahun dengan $\mathrm{CH}>50$ $\mathrm{mm}$ dan hari hujan $\leq 4(\mathrm{HH})$. Pada gambar tersebut terlihat bahwa musim kemarau dengan nilai $\mathrm{CH}$ sebesar $\leq 50 \mathrm{~mm}$.

\subsection{Sungai Pakning}

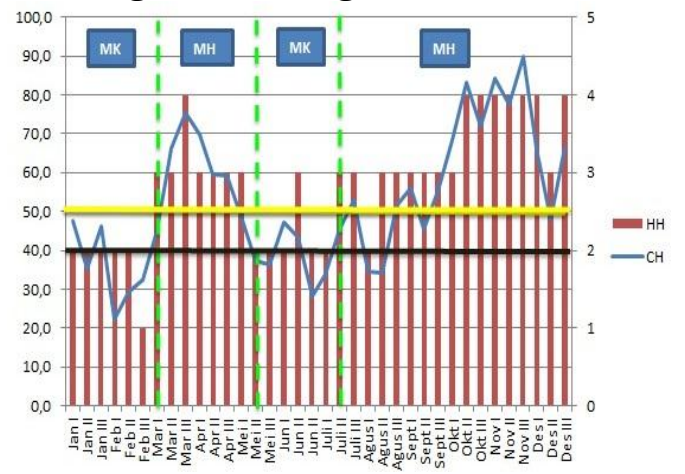

Gambar 7 Musim hujan Sei Pakning Periode Ke-I
Gambar diatas menunjukkan kondisi Sungai Pakning terjadi musim hujan pada periode I dengan curah hujan $(\mathrm{CH})<50 \mathrm{~mm}$ dan hari hujan < $2(\mathrm{HH})$. Pada gambar tersebut terlihat bahwa musim hujan dengan nilai $\mathrm{CH}$ sebesar $\geq 90 \mathrm{~mm}$. Musim hujan terjadi pada bulan Maret I sampai bulan Mei II kemudian tejadi kembali pada bulan Juli II sampai bulan Desember II

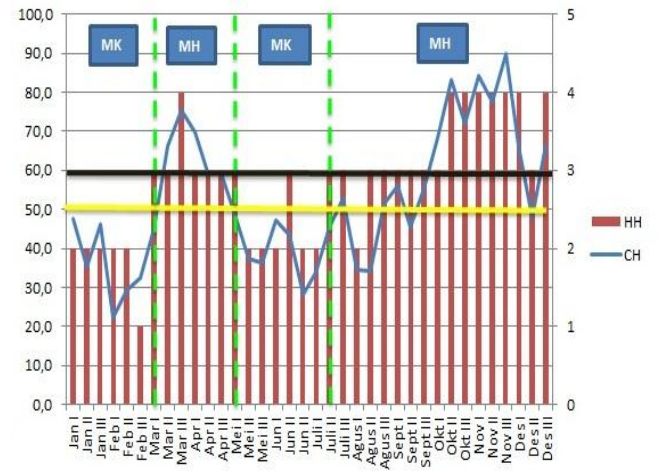

Gambar 8 Musim Hujan Sei Pakning Periode Ke-II

Gambar diatas menunjukkan kondisi Sei. Pakning mengalami musim hujan pada periode II dengan curah hujan $(\mathrm{CH})>50 \mathrm{~mm}$ dan hari hujan $\geq 3(\mathrm{HH})$ Pada gambar tersebut terlihat bahwa musim hujan dengan nilai $\mathrm{CH}$ sebesar $\geq 90 \mathrm{~m}$. Musim hujan terjadi pada bulan Maret I sampai Mei I kemudian musim hujan terjadi kembali pada bulan Juli II sampai bulan Desember II. Selain itu, dari gambar diatas terlihat untuk daerah Sei Pakning periode ke-II memiliki musim hujan lebih panjang dibandingkan periode ke-I.

\subsection{Daerah NON ZOM 14}

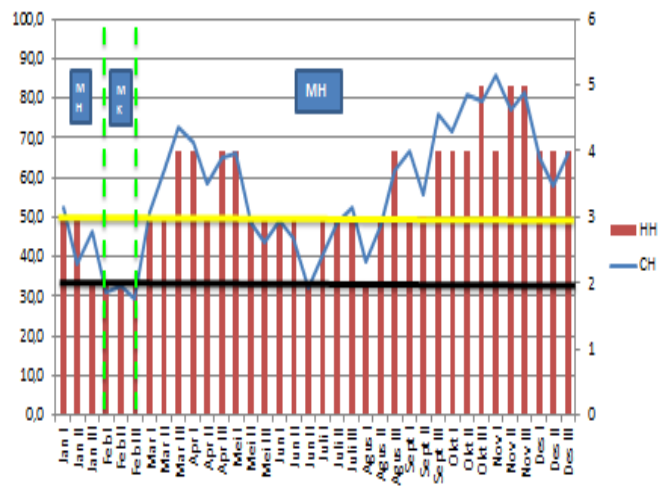

Gambar 9 Non ZOM 14 Periode Ke-I

Berdasarkan gambar diatas menunjukkan daerah NON ZOM 14 memiliki musim hujan dengan hari hujan $<2(\mathrm{HH})$. Diperoleh musim hujan dengan nilai $\mathrm{CH}$ sebesar $>80 \mathrm{~mm}$. Pada gambar tersebut terlihat bahwa musim hujan hampir terjadi 
pada setiap bulan dimulai dari bulan Feb II sampai bulan Desember III

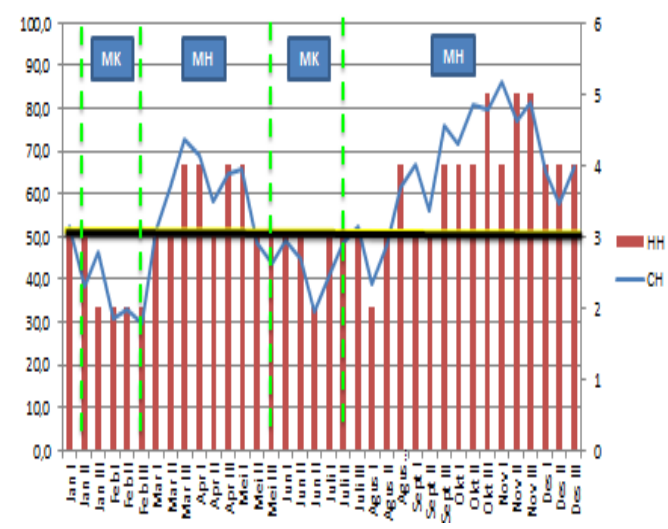

Gambar 10 Non ZOM 14 Periode Ke-II

Berdasarkan gambar diatas menunjukkan daerah NON ZOM 14 memiliki musim hujan dengan hari hujan $>3(\mathrm{HH})$ dan besar curah hujan yang terjadi pada musim hujan sebesar $\geq 80 \mathrm{~mm}$. Musim hujan terjadi pada bulan Feb III sampai bulan Mei III kemudian terjadi kembali musim hujan pada bulan Agustus III sampai bulan Desember III dengan nilai $\mathrm{CH}$ sebesar $\geq 80 \mathrm{~mm}$. Musim kemarau terjadi pada bulan Jan II sampai bulan Feb II kemudian terjadi pada bulan Mei II sampai bulan Juli II dan memiliki besar curah hujan $\geq 30 \mathrm{~mm}$

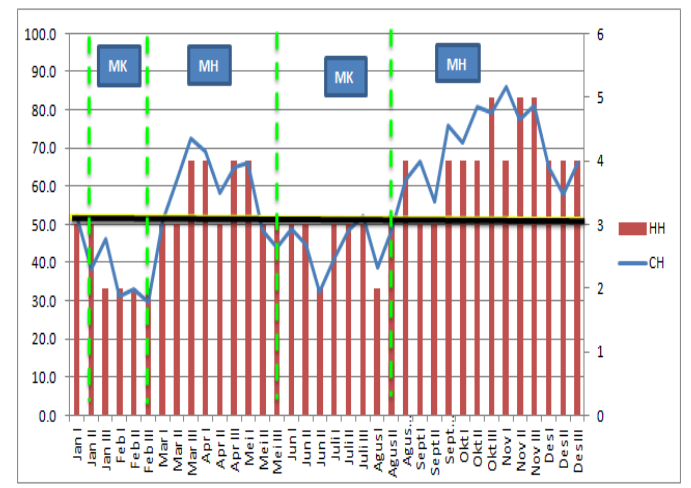

Gambar 11 Non ZOM 14 Periode Ke-III

Berdasarkan gambar diatas menunjukkan daerah musim hujan di daerah Non ZOM 14 Riau terjadi pada hari hujan $\geq 4(\mathrm{HH})$. Pada gambar tersebut terlihat bahwa musim hujan dengan nilai $\mathrm{CH}$ sebesar $\geq 80 \mathrm{~mm}$ yang terjadi pada bulan Maret I sampai bulan Mei II dan terjadi kembali pada bulan Agustus III sampai bulan Desember III. Musim kering terjadi pada bulan Januari I sampai bulan Feb III dan terjadi kembali pada bulan Mei II sampai bulan Juli II dengan besar $\mathrm{CH} \leq 3 \mathrm{~mm}$.

Dari ketiga gambar penentuan musim di atas untuk daerah Non ZOM 14 di atas menunjukkan adanya hubungan secara korelasi antara Non ZOM dengan data $\mathrm{CH}$ dasarian dan $\mathrm{HH}$ dasarian.

\section{KESIMPULAN}

Berdasarkan penelitian yang yang telah dilakukan dengan melakukan pengolahan data $(\mathrm{CH})$ curah hujan dasarian dan $(\mathrm{HH})$ hari hujan dasarian dapat simpulkan bahwa:

1. Daerah Dumai memiliki awal musim hujan $(\mathrm{AMH})$ dengan hari hujan $\geq 3(\mathrm{HH})$ dan awal musim kemarau (AMK) dengan hari hujan sebesar $\leq 3(\mathrm{HH})$ sedangkan untuk daerah Sei. Pakning memiliki awal musim hujan (AMH) dengan besar hari hujan $\geq 3(\mathrm{HH})$ sedangkan untuk awal musim kemarau (AMK) tidak terlalu terlihat.

2. Daerah Dumai dan Sei. Pakning memiliki korelasi dengan Non ZOM (zona musim) dengan menggunakan metode jumlah $\mathrm{CH}$ dasarian dan $\mathrm{HH}$ dasarian. Sehingga terdapatnya pola musim hujan dan musim kemarau di daerah Dumai dan Sei. Pakning

3. Daerah Dumai dan Sei. Pakning tidak bisa dikategorikan sebagai daerah Non Zom 14

Adapun saran dari penelitian ini sebagai berikut:

1. Sebaiknya data yang digunakan untuk daerah Sei. Pakning menggunakan data normal

2. Untuk data normal Curah Hujan 1991-2020 sebaiknya Non Zom 14 dihilangkan menjadi ZOM (Zona Musim)

\section{DAFTAR PUSTAKA}

Aldrian, E, Budiman, dan Mimin Karmini. 2011. Adaptasi dan Mitigasi Perubahan Iklim di Indonesia. Pusat Perubahan Iklim dan Kualitas Udara Kedeputiann Bidang Klimatologi, Badan Meteorologi, Klimatologi dan Geofisika. Jakarta.

Asdak, C., 2002. Hidrologi dan Pengelolaan Daerah Aliran Sungai. Gajah Mada University Press. Yogyakarta.

Bayong, Tj. H. K. 2004. Klimatatologi. ITB. Bandung.

Boer R. 2002. Fenomena ENSO dan Hubungannya Dengan Keragaman Hujan di Indonesia dalam Pelatihan Dosen PT Se-Sumatera-Kalimantan dalm Bidang Pemodelan dan Simulasi Pertanian dan Lingkungan, Bogor, 1-13 Juli 2002.

BMKG. 2010. Zona Musim Riau. Rapat Awal Musim Hujan 2010/2011. BMKG: Jakarta

BMKG. 2014. Prakiraan Musim Hujan 2014/2015 Di Indonesia. BMKG: Jakarta

Gibbs, K. H., S. Brown, J. O Niles, J. A. Foley. Monitoring And Estimating Tropical 
Forest Carbon Stocks: Making REDD a Reality. IOP Publishing.

Handajani, N. 2005., Analisa distribusi Curah Hujan dengan Kala Ulang Tertentu, Jurnal Rekayasa Perencanaan, Vol 1. No.3, Juni 2006, Hal 46-57

Koenker, R. and Basset, G. 1978. Regression Quantile, Econometrica. January, 46:1, pp. 33-50

Koenker, R. and Hallock, K.F. 2001. Quantile Regression, The Journal of EkonomicPerspectives, Vol. 15, No. 4, pp. 143-156 Published by: American Economic Association.

Koenker, R. 2005. Quantile Regression. Cambridge: Cambridge University Press. Roger , R., (1980). Cloud Physics. Pergamon Press. New York

Lakitan, B. 2002. Dasar-Dasar Klimatologi. Cetakan Ke-2. Raja Grafindo Persada. Jakarta.

Mulyana, E. 2002. Hubungan Antara ENSO Dengan Variasi Curah Hujan Di Indonesia. Jurnal. Jurnal Sains \& Teknologi Modifikasi Cuaca, Vol. 3, No. 1, 2002: 1 -4

Prawirowardoyo, S. 1996. Meteorologi. Bandung: Penerbit ITB

Subarno, D. 2002. "Cuaca: Sistem Kompleks". Dalam Kompas. 3 Mei. Hal. 45

Susandi, A., I. Herlianti, M. Tamamadin, I. Nurlela. 2008. Dampak Perubahan Iklim terhadap Ketinggian Muka Laut di Wilayah Banjarmasin. Jurnal Ekonomi Lingkungan. Volume 12, No 2.

Tjasyono,B.HK. 2006. Ilmu Kebumian dan Antariksa. Bandung: PT. Remaja Rosdakarya bekerjasama dengan Program Pascasarjana UPI

Thewartha , R. (1980). Global Climate. Journal ( page : 3 ). New York

Tukidi. 2010. Karakter Curah Hujan Di Indonesia. Jurusan Geografi FIS UNNES. Volume 7 No. 2 Juli 2010

Trewartha, G.T., \& Horn, L.H. (1980). An intr oduction to climate. New $Y$ ork: McGraw-Hill.

Ulfah, A., dan Nuryadi. 2014. Pembahasan Kriteria Awal Musim Hujan dan Kemarau. Skripsi. Klimatologi STMKG. Jakarta 